\title{
Interaction of gypsum with lead in aqueous solutions
}

\author{
J.M. Astilleros ${ }^{\mathrm{a}, \boldsymbol{}}$, A. Godelitsas ${ }^{\mathrm{b}}$, J.D. Rodríguez-Blanco ${ }^{\mathrm{c}}$, L. Fernández-Díaz ${ }^{\mathrm{a}}$, M. Prieto ${ }^{\text {a }}$, \\ A. Lagoyannis ${ }^{\mathrm{e}}$, S. Harissopulos ${ }^{\mathrm{e}}$ \\ ${ }^{a}$ Dpto. Cristalografia y Mineralogía, Universidad Complutense de Madrid, José Antonio Novais, 2, E-28\4 Madrid, Spain \\ ${ }^{b}$ Department of Mineralogy and Petrology, Faculty of Geology \& Geoenvironment, University of Athens, Panepistimioupoli Zographou, 15784 Athens, Greece \\ 'School of Earth and Environments, Faculty of Environment, The University of Leeds, Leeds IS2 9JT, United Kingdom \\ apto. de Geologia, Universidad de Oviedo, E-30005 Oviedo, Spain \\ "Tandem Accelerator Laboratory, Institute of Nuclear Physics, NCSR "Demokritos", GR-1531 Attiki, Greece
}

\begin{abstract}
A B S T R A C T
Sorption processes on mineral surfaces are a critical factor in controlling the distribution and accumulation of potentially harmful metals in the environment. This work investigates the effectiveness of gypsum $\left(\mathrm{CaSO}_{4} \cdot 2 \mathrm{H}_{2} \mathrm{O}\right)$ to sequester $\mathrm{Pb}$. The interaction of gypsum fragments with Pb-bearing solutions $(10,100$ and $1000 \mathrm{mg} / \mathrm{L}$ ) was monitored by performing macroscopic batch-type experiments conducted at room temperature. The aqueous phase composition was periodically determined by Atomic Absorption Spectrometry (AAS), Ion Chromatography (IC) and Inductively Coupled Plasma Optical Emission Spectroscopy (ICP-OES). Regardless of the $\left[\mathrm{Pb}_{\mathrm{aq}}\right]_{\text {initial }}, \mathrm{a}\left[\mathrm{Pb}_{\mathrm{aq}}\right]_{\text {final }}<4 \mathrm{mg} / \mathrm{L}$ was always reached. The uptake process was fast $(t<1 \mathrm{~h})$ for $\left[\mathrm{Pb}_{\mathrm{aq}}\right]_{\text {initial }} \geqslant 100 \mathrm{mg} / \mathrm{L}$ and significantly slower $\left(t>1\right.$ week) for $\left[\mathrm{Pb}_{\mathrm{aq}}\right]_{\text {initial }}=10 \mathrm{mg} / \mathrm{L}$. Speciation calculations revealed that after a long time of interaction ( $1 \mathrm{month})$, all the solutions reached equilibrium with respect to both gypsum and anglesite. For $\left[\mathrm{Pb}_{\mathrm{aq}}\right]_{\text {initial }} \geqslant 100 \mathrm{mg} / \mathrm{L}$, sorption takes place mainly via the rapid dissolution of gypsum and the simultaneous formation of anglesite both on the gypsum surface and in the bulk solution. In the case of $\left[\mathrm{Pb}_{\mathrm{aq}}\right]_{\text {initial }}=10 \mathrm{mg} / \mathrm{L}$, no anglesite precipitation was observed, but surface spectroscopy (proton Rutherford Backscattering Spectroscopy, p-RBS) confirmed the formation of $\mathrm{Pb}$-bearing surface layers on the $\left(\begin{array}{ll}0 & 10\end{array}\right)$ gypsum surface in this case also. This study shows that the surface of gypsum can play an important role in the attenuation of $\mathrm{Pb}$ in contaminated waters.
\end{abstract}

\section{Introduction}

Although several international organizations classify $\mathrm{Pb}$ at the top of the priority list of the most hazardous substances (immediately after As according to the US Environmental Protection Agency), it is still extensively used in many industrial applications such as in batteries, pigments, ammunition, devices to shield $\mathrm{X}$-rays, roofing and photographic material. Although its use as an additive to gasoline has been banned in most industrialized countries, it is still in use in several developing countries. The same applies for the use of $\mathrm{Pb}$ in applications such as water pipes (Tukker et al., 2006). As a result, the worldwide anthropogenic inputs of $\mathrm{Pb}$ to freshwaters and the atmosphere are in the range of several thousand of tonnes/a that gradually accumulate in the geo- and biosphere (Nriagu and Pacyna, 1988). Even so, the most catastrophic effects of $\mathrm{Pb}$ emission arise when its release to the environment occurs inevitably in areas close to tailings and waste water from mines (Simón et al., 1999).

\footnotetext{
* Corresponding author. Fax: +34 913944872.

E-mail address: jmastill@geo.ucm.es (J.M. Astilleros).
}

It is well known that the degree of $\mathrm{Pb}$ mobility depends on several geochemical factors, $\mathrm{pH}$ and the specific mineralogy of the surrounding areas being among the most important ones (Lin et al., 1995). Lead sorption processes taking place at the mineral - aqueous solution interface can lead to the removal of $\mathrm{Pb}$ from polluted waters with an efficiency close to $100 \%$ under certain conditions (Traina and Laperche, 1999; Godelitsas et al., 2003a; Martin et al., 2008). Several minerals, such as silicates, oxides/oxyhydroxides (Cortina et al., 2003), carbonates (Godelitsas et al., 2003a) and the apatite mineral group (Valsami-Jones et al., 1998; Lower et al., $1998 \mathrm{a}, \mathrm{b})$ have been proposed as effective candidates for the immobilization of $\mathrm{Pb}$. More recently, synthetic materials derived from phosphate technology, such as Apatite II ${ }^{\mathrm{TM}}$ (Conca and Wright, 2001), a by-product of the fishing industry, have been proposed for $\mathrm{Pb}$ remediation (Conca and Wright, 2006).

Following this research line, an experimental study of the interaction of $\mathrm{Pb}$-bearing aqueous solutions with gypsum $\left(\mathrm{CaSO}_{4} \cdot 2 \mathrm{H}_{2} \mathrm{O}\right)$ fragments is presented here. The choice of this material is based on the fact that its chemical behavior in the presence of $\mathrm{Pb}$ is expected to be similar to that of $\mathrm{Ca}$ carbonates and $\mathrm{Ca}$ phosphates, namely rapid dissolution of the substrate followed by the formation of a 
sparingly soluble $\mathrm{Pb}$-bearing solid phase, presumably $\mathrm{PbSO}_{4}$ (anglesite) in this case. Among sedimentary rock-forming minerals, gypsum emerges as potentially useful to take up a broad spectrum of dissolved metals, particularly $\mathrm{Pb}$, because of (1) the high reactivity of its surfaces, which makes it much more soluble $\left(K_{\mathrm{sp}}=10^{-4.58}\right.$. Parkhurst and Appelo, 1999) than $\mathrm{CaCO}_{3}$ and apatite; (2) the relative non-toxicity of both dissolved $\mathrm{Ca}$ and $\mathrm{SO}_{4}$ (in comparison to $\left.\mathrm{PO}_{4}\right)$; and (3) its abundance in nature. Few studies have examined the interaction of $\mathrm{SO}_{4}^{2-}$ ions with dissolved $\mathrm{Pb}$ and most of them have focused on acid mine drainage and weathering of sulfidic mineral wastes (Bigham and Nordstrom, 2000; Blowes et al., 2005; Lottermoser, 2007). In such environments, gypsum is one of the most abundant and widespread of the post-mining secondary minerals (Blowes et al., 2005). Gypsum re-dissolution will release its component ions back into solution (Lottermoser, 2007) and as a consequence, new reactions will occur. Sulfate ions will quickly react with $\mathrm{Pb}$ to form highly insoluble anglesite $\left(K_{\mathrm{sp}}=10^{-7.79}\right.$; Parkhurst and Appelo, 1999) according to the following equations:

$\mathrm{CaSO}_{4} \cdot 2 \mathrm{H}_{2} \mathrm{O}_{(\mathrm{s})}+n \mathrm{H}_{2} \mathrm{O}_{(1)} \rightarrow \mathrm{Ca}_{(\text {aq) }}^{2+}+\mathrm{SO}_{4(\mathrm{aq})}^{2-}+n \mathrm{H}_{2} \mathrm{O}_{(1)}$

$\mathrm{SO}_{4(\mathrm{aq})}^{2-}+\mathrm{Pb}_{(\text {aq })}^{2+} \rightarrow \mathrm{PbSO}_{4(\mathrm{~s})}$

According to this the presence of gypsum may contribute to removing significant quantities of $\mathrm{Pb}$, providing a natural attenuation mechanism in mine-drainage water (Lin and Herbert, 1997: $\mathrm{Lin}, 1997)$. The reaction of $\mathrm{SO}_{4}^{2-}$ with $\mathrm{Pb}$ to give anglesite has also been described in soils where the flux of $\mathrm{Pb}$ is high and constant, such as in the soil of shooting ranges, where the $\mathrm{Pb}$-input comes from shotgun pellets (Lin et al., 1995).

No previous detailed experimental study has been carried out to date on this system. The main objective of this work is, therefore, to gain a better understanding of the kinetics of the dissolution/ precipitation reactions occurring as a result of the interaction between gypsum and Pb-bearing waters. In this way, a study is presented on the effectiveness of gypsum as a Pb-sequestering agent using macroscopic batch-type experiments, having monitored the changes in Pb-bearing aqueous solutions with wet-chemical analyses and characterized the solids by X-ray diffraction, high-resolution microscopy and surface spectroscopy.

\section{Experimental}

\subsection{Macroscopic experiments in batch reactors}

The gypsum specimens (selenite variety) used in all experiments were crystals from Teruel, Spain. X-ray fluorescence spectroscopy (XRF) and X-ray diffraction (XRD) analysis confirmed that the starting material corresponded to highly pure gypsum containing less than $0.2 \mathrm{wt} . \%$ impurities. The investigation was based on a macroscopic closed batch-type treatment procedure. Experiments were carried out by placing $2 \mathrm{~g}$ of crushed gypsum crystals (1.0-1.4 mm fragments obtained using an agate mortar) and $100 \mathrm{~mL}$ of Pb-bearing aqueous solution in an Azlon beaker stirred at 500-700 rpm and kept at room temperature $\left(25 \pm 1{ }^{\circ} \mathrm{C}\right)$ under atmospheric $P_{\mathrm{Ca}_{2}}$. The parent solutions were prepared using reagent-grade $\mathrm{Pb}\left(\mathrm{NO}_{3}\right)_{2}$ and high-purity deionized water (resistivity: $18 \mathrm{M} \Omega \mathrm{cm}$ ) to yield $\left[\mathrm{Pb}_{\mathrm{aq}}\right]_{\text {initial }}$ of 10,100 and $1000 \mathrm{mg} / \mathrm{L}$. The solid-liquid ratio used in the experiments was always $0.02 \mathrm{~g} / \mathrm{mL}$ ( $2 \mathrm{~g}$ of gypsum in $100 \mathrm{~mL}$ aqueous solution). Although such high $\mathrm{Pb}$ conditions are not representative of most natural environments, they are consistent with highly Pb-contaminated sites, where $\left[\mathrm{Pb}_{\mathrm{aq}}\right]$ can be much higher than $100 \mathrm{mg} / \mathrm{L}$ (Lower et al., 1998a,b; Ma et al., 1993). In addition, such experimental conditions are similar to previous sorption and dissolution studies (Godelitsas et al., 2003a; Lower et al., 1998a,b). Independent experimental runs were carried out for each concentration of $\mathrm{Pb}\left(\mathrm{NO}_{3}\right)_{2}$ in aqueous solution. Each experiment was triplicated in order to confirm experimental reliability. After specific reaction periods ranging from $1 \mathrm{~min}$ to $744 \mathrm{~h}$ ( 1 month), experiments were stopped and a small portion of the solution $(10 \mathrm{~mL})$ was immediately extracted, filtered through a $0.45-\mu \mathrm{m}$ cellulose acetate filter, and analyzed. The evolution of the aqueous solution composition was monitored using AAS (PYE-UNICAM SP9), IC (Metrohm Advanced Compact 861 IC) and ICP-OES (Perkin-Elmer-Optima-3300-DV) in the case of those solutions that had been in contact with gypsum for 1 month. The solution $\mathrm{pH}$ was measured with a combination electrode (RossThermo-Orion 810200) and a digital pH-meter (CyberScan pH 2100, Eutech Ins.). Multipoint calibration of the electrode was performed with 4.01, 7.00, and 10.01 NIST-traceable buffers (ThermoOrion). Activities of metal ions and saturation indices for the solid phases involved were calculated using the geochemical code PHREEQC (Parkhurst and Appelo, 1999). X-ray diffraction patterns (XRD) were used to identify the phase(s) formed during the crystal-solution interaction. The diffractometer used was a Philips X'Pert MPD equipped with a $\mathrm{Cu} \mathrm{K} \alpha \mathrm{X}$-ray source.

\subsection{Experiments using individual single crystals}

Experiments were carried out by submerging optically clear gypsum crystals cleaved on (010) faces in 1-mL volumes of aqueous solutions of $\mathrm{Pb}\left(\mathrm{NO}_{3}\right)_{2}$. The size of the gypsum crystals was approximately $3 \times 3 \times 0.8-1 \mathrm{~mm}$. In these experiments the solidliquid ratio was $\approx 0.02 \mathrm{~g} / \mathrm{mL}$, which is the ratio used in the experiments performed using batch reactors. Since gypsum crystals cleaved preferentially on ( 010$)$, most of the surface area exposed to the aqueous solutions corresponded to this face. The Pb-bearing solutions were prepared in the same way as described in the previous section $\left(\left[\mathrm{Pb}_{\mathrm{aq}}\right]_{\text {initial }}=10,100\right.$ and $\left.1000 \mathrm{mg} / \mathrm{L}\right)$.

Independent experiments were carried out for each concentration of $\mathrm{Pb}$ in the aqueous solution. Gypsum crystals were removed from the solutions after different reaction periods, ranging from $1 \mathrm{~min}$ to $168 \mathrm{~h}$ ( 1 week). In all cases, crystals were rapidly dried by blowing pressurized air on their surfaces. All the experiments were carried out at $25^{\circ} \mathrm{C}$ and atmospheric pressure. Each experiment was repeated at least three times in order to confirm experimental reliability.

The samples obtained by the procedure described above were studied by standard scanning electron microscopy (SEM) (JEOL JSM $6400,40 \mathrm{kV})$. SEM imaging of the gypsum $\left(\begin{array}{lll}0 & 1 & 0\end{array}\right)$ surface provided information about textural and mineralogical features. Energy-dispersive X-ray spectroscopy (EDX) analyses were carried out on selected areas of the samples. Glancing Incidence X-ray diffraction patterns (GIXRD) were used to identify the phase(s) formed during the crystal-solution interaction. The diffractometer used was a Philips X'Pert PRO MRD equipped with a Cu K $\alpha$ X-ray source. The small angle of incidence $\left(1^{\bullet}\right)$ allows one to obtain information corresponding to the shallower layers.

The proton Rutherford Backscattering Spectroscopy (p-RBS) provided information on the elemental distribution on the $\mathrm{Pb}$-affected surface. Measurements were carried out on gypsum ( $\left.\begin{array}{lll}0 & 10\end{array}\right)$ surfaces previously interacted with aqueous solutions containing $\left[\mathrm{Pb}_{\mathrm{aq}}\right]_{\text {initial }}$ equal to 10 and $100 \mathrm{mg} / \mathrm{L}$. In this case, crystals were separated from aqueous solutions after reaction periods of $0.5 \mathrm{~h}, 72 \mathrm{~h}$ ( 3 days) and $168 \mathrm{~h}$ ( 1 week). The p-RBS method is based on the fact that for low beam energies (less than $2 \mathrm{MeV}$ ), the backscattered protons from the sample are obeying Rutherford's formula. The number of the detected protons gives information about the stoichiometry of the sample. Since the energy of the detected protons is proportional to the atomic mass $A$ of the nuclei with which they interact, proton energies provide information on the atom species in the sample. Protons progressively lose energy during their 
propagation through the sample due to the interaction with electrons. This effect can be used to extract information about the depth profiling of the atom species. The whole analysis of the accumulated spectrum requires the application of simulation codes, which take into account all these effects. In the case under consideration, the interacted gypsum crystal surfaces were analyzed at the 5.5 MV Tandem Accelerator Laboratory of NCSR "Demokritos" (Athens, Greece) using an $1 \mathrm{MeV}$ proton beam. The beam current was kept constant ( $10 \mathrm{nA})$ during all irradiations. The spot size of the proton beam was c. $2 \times 2 \mathrm{~mm}^{2}$. The backscattered protons were detected at a scattering angle of $170^{\bullet}$ with respect to the beam axis with a silicon surface barrier detector of $300 \mu \mathrm{m}$ thickness covering a solid angle of $1.25 \mathrm{msr}$. The whole set-up was housed in a C. Evans \& Assoc. scattering chamber equipped with a computer-controlled precision goniometer. The chamber was kept under vacuum $\left(10^{-7} \mathrm{mTorr}\right)$ with the aid of two turbo pumps. The accumulated spectra were recorded applying a gradually increased penetration of the ion-beam, using nanometer-sized steps, until no $\mathrm{Pb}$ was detected. The maximum thickness of the Pb-rich surface layer was calculated taking into consideration the density of gypsum and assuming that $\mathrm{Pb}$-sorbed compounds/species could be both anhydrous and hydrated. The spectra simulation and the quantification of the element distribution was carried out using the SIMNRA software package (Mayer, 2002).

\section{Results}

\subsection{Macroscopic experiments in batch reactors}

Fig. 1a shows the evolution of $\mathrm{Pb}$ concentrations as a function of time for the sorption experiments performed with $2 \mathrm{~g}$ of $1.0-$ $1.4 \mathrm{~mm}$ gypsum fragments in contact with an aqueous solution containing $\left[\mathrm{Pb}_{\mathrm{aq}}\right]_{\text {initial }}$ of $1000 \mathrm{mg} / \mathrm{L}$. The $\mathrm{Pb}$ concentration fell dramatically during the first minutes of the experiments. In order to observe more accurately the evolution of the $\mathrm{Pb}$ concentration, a broken axes graphic is inserted in Fig. 1a. After 5 min of reaction, more than $60 \%$ of the $\mathrm{Pb}$ was removed from solution. The $\mathrm{Pb}$ uptake progressed rapidly and after $25 \mathrm{~min}$ of reaction only $\sim 10 \mathrm{mg} / \mathrm{L}$ of $\mathrm{Pb}\left(1 \%\right.$ of the $\left.\left[\mathrm{Pb}_{\mathrm{aq}}\right]_{\text {initial }}\right)$ remained in the solution. Beyond this point, the concentration of $\mathrm{Pb}$ in the solution decreased very slowly until reaching a final value close to $3.0 \mathrm{mg} / \mathrm{L}$. After a few seconds of interaction, the aqueous solution became cloudy and whitish, likely indicating a precipitation reaction was taking place. In order to characterize the small particles formed during the reaction, a XRD analysis was performed on a sample of the precipitate separated from the solution using a $0.45-\mu \mathrm{m}$ cellulose acetate filter. The XRD analysis (Fig. 2) indicated that the precipitate consisted of anglesite ( $\mathrm{PbSO}_{4}$ - JCPDS card number 05-0577).

In the case of $\left[\mathrm{Pb}_{\mathrm{aq}}\right]_{\text {initial }}=100 \mathrm{mg} / \mathrm{L}$ (Fig. $1 \mathrm{~b}$ ), the evolution of the $\mathrm{Pb}$ content followed a trend very similar to that described above for solutions with $\left[\mathrm{Pb}_{\mathrm{aq}}\right]_{\text {initial }}=1000 \mathrm{mg} / \mathrm{L}$. The concentration of $\mathrm{Pb}$ rapidly dropped during the first minutes to reach a concentration around $\sim 6 \mathrm{mg} / \mathrm{L}$ after $30 \mathrm{~min}$ of interaction. This drop was followed by a near complete halt of the uptake process. As in the previous case, the $\mathrm{Pb}$ concentration approached a limiting value close to $\sim 3 \mathrm{mg} / \mathrm{L}$ after one month of interaction.

The kinetics of $\mathrm{Pb}$ uptake observed in the experiments performed using solutions with $\left[\mathrm{Pb}_{\mathrm{aq}}\right]_{\text {initial }}=10 \mathrm{mg} / \mathrm{L}$ strongly contrasts with the behavior described in the previous cases (Fig. 1c). In this case, the $\mathrm{Pb}$ concentration decreases gradually. Moreover, no significant change was detected during a relatively long initial period ( 1 day). Afterwards, $\mathrm{Pb}$ concentration drop occurred very slowly to reach a final value of $\sim 3.8 \mathrm{mg} / \mathrm{L}$ after $1 \mathrm{month}$ of interaction. This value is higher than the limiting $\mathrm{Pb}$ concentration reached in the two previous experiments for the same time of
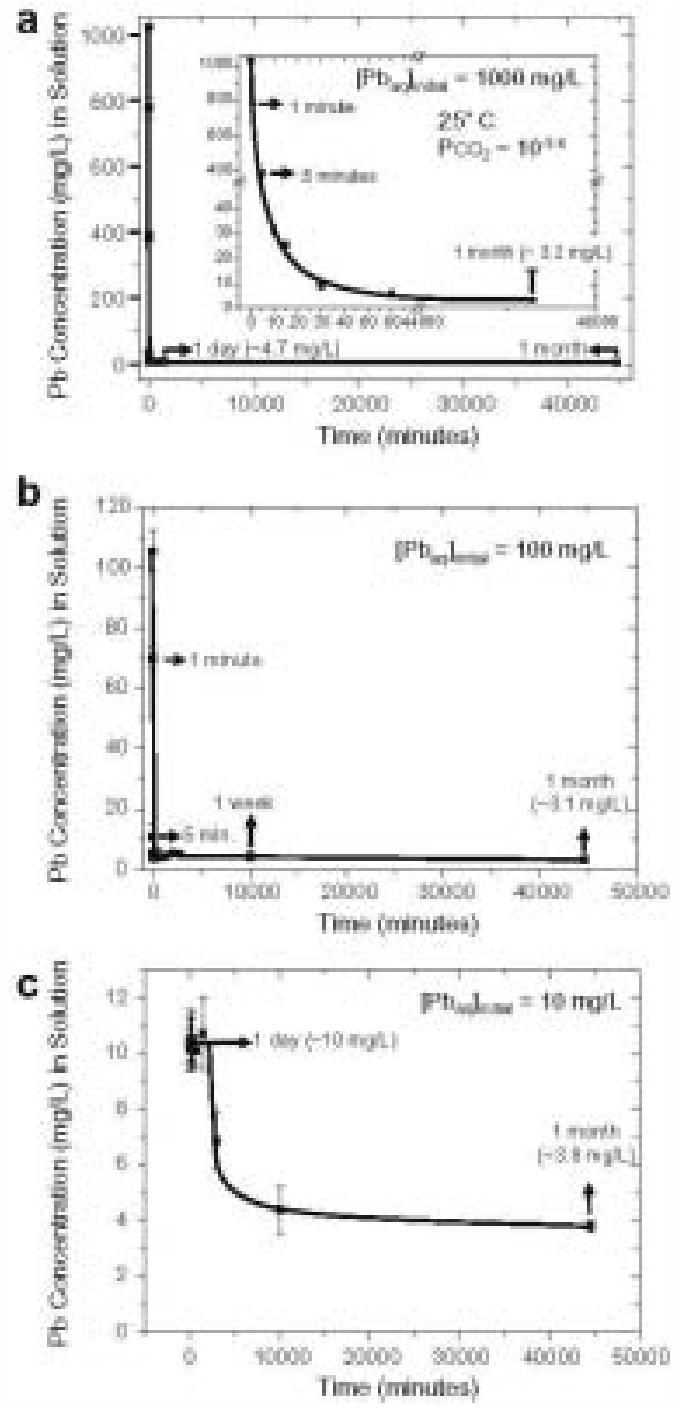

Fig. 1. Evolution of $\mathrm{Pb}$ concentration as a function of time during the interaction of gypsum fragments with $\mathrm{Pb}$-solutions. (a) $\left[\mathrm{Pb}_{\text {aq }}\right]_{\text {initial }}=1000 \mathrm{mg} / \mathrm{L},(\mathrm{b})\left[\mathrm{Pb}_{\text {a }}\right]_{\text {initial }}=$ $100 \mathrm{mg} / \mathrm{L}$ and $(\mathrm{c})\left[\mathrm{Pb}_{a \mathrm{a}}\right]_{\text {initial }}=10 \mathrm{mg} / \mathrm{L}$.

interaction. Moreover, the $\mathrm{Pb}$ concentration in the aqueous solutions after 1 day of interaction was much lower $\left(\left[\mathrm{Pb}_{\mathrm{aq}}\right]_{1}\right.$ day $\approx 4.5 \mathrm{mg} / \mathrm{L})$ when $\left[\mathrm{Pb}_{\mathrm{aq}}\right]_{\text {initial }}$ was high $\left(\left[\mathrm{Pb}_{\mathrm{aq}}\right]_{\text {initial }}=1000 \mathrm{mg} /\right.$ $\mathrm{L})$ or moderate $\left(\left[\mathrm{Pb}_{\mathrm{aq}}\right]_{\text {initial }}=100 \mathrm{mg} / \mathrm{L}\right)$ than when it was low $\left(\left[\mathrm{Pb}_{\mathrm{aq}}\right]_{\text {initial }}=\left[\mathrm{Pb} \mathrm{Paq}_{1 \text { day }}=10 \mathrm{mg} / \mathrm{L}\right)\right.$. Therefore, it can be concluded that the kinetics of $\mathrm{Pb}$ sorption as a result of interaction with gypsum is much more sluggish when the concentration of $\mathrm{Pb}$ in the solution is low than when high to moderate concentrations are considered.

Fig. 3 shows the change in the concentration of $\mathrm{Ca}, \mathrm{SO}_{4}^{2-}$ and $\mathrm{Pb}$ as a function of time when a solution with $\left[\mathrm{Pb}_{\mathrm{aq}}\right]_{\text {initial }}=1000 \mathrm{mg} / \mathrm{L}$ is used. The concentration of both $\mathrm{Ca}$ and $\mathrm{SO}_{4}^{2-}$ increased rapidly during the first minutes of interaction to reach a plateau value after 120 min of the reaction. The drop in the $\mathrm{Pb}$ concentration also occurs rapidly during the first minutes of the reaction to reach a limiting value. Such an evolution trend indicates that the removal of $\mathrm{Pb}$ and the release of $\mathrm{Ca}$ and $\mathrm{SO}_{4}^{2-}$ to the solution are concomitant during the whole length of the experiment. A similar trend has also been observed in the experiments carried out using a solution with $\left[\mathrm{Pb}_{\mathrm{aq}}\right]_{\text {initial }}=100 \mathrm{mg} / \mathrm{L}$.

The initial measured $\mathrm{pH}$ values were $4.80 \pm 15,5.30 \pm 10$ and $5.50 \pm 10$ for solutions with $\left[\mathrm{Pb}_{\mathrm{aq}}\right]_{\text {initial }}$ of 1000,100 , and $10 \mathrm{mg} / \mathrm{L}$, 


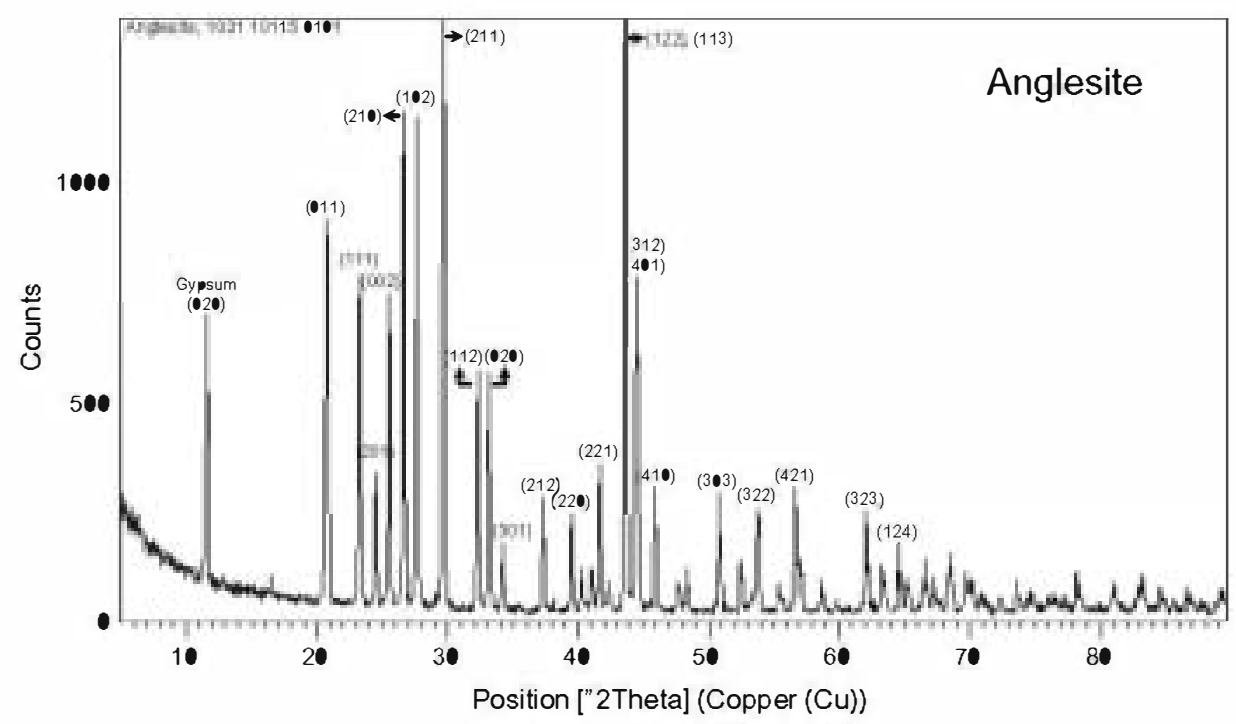

Fig. 2. XRD pattern for precipitates obtained after $30 \mathrm{~min}$ of reaction of gypsum fragments with $\left[\mathrm{Pb}_{\mathrm{aq}}\right]_{\text {initial }}=1000 \mathrm{mg} / \mathrm{L}$.

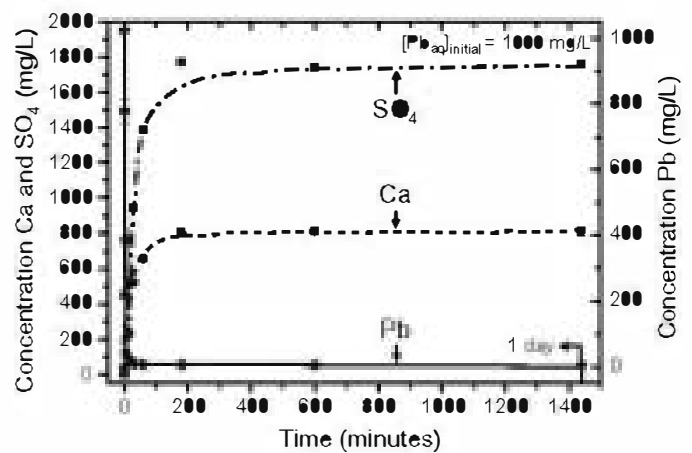

Fig. 3. Evolution of $\mathrm{Ca}, \mathrm{SO}_{4}^{2}$ and $\mathrm{Pb}$ concentrations as a function of time during the interaction of gypsum fragments with $\mathrm{Pb}$-bearing solutions ( $\left[\mathrm{Pb}_{\mathrm{aq}}\right]_{\text {initial }}=1000 \mathrm{mg}$ ) $\mathrm{L})$. The uptake of $\mathrm{Pb}$ from solution and the release of $\mathrm{Ca}$ and $\mathrm{SO}_{4}^{2}$ occurred in parallel until the end of the experiment.

respectively. During the reaction with gypsum the $\mathrm{pH}$ of the aqueous solutions underwent a slight increase, to reach a final value of $5.60 \pm 20$. This relatively low $\mathrm{pH}$ prevents the formation of solid phases other than anglesite.

\subsection{Experiments using individual single crystals}

\subsubsection{SEM observations}

The SEM images obtained after different periods of exposure of the gypsum $\left(\begin{array}{lll}0 & 1 & 0\end{array}\right)$ surface to the $\mathrm{Pb}\left(\mathrm{NO}_{3}\right)_{2}$ solutions show that the reaction begins immediately the crystal is in contact with the solution, irrespective of the $\left[\mathrm{Pb}_{\mathrm{aq}}\right]_{\text {initial }}$ used. However, $\left[\mathrm{Pb}_{\mathrm{aq}}\right]_{\text {initial }}$ strongly controls the characteristics of the reaction. Fig. 4 shows a sequence of images of gypsum (0 1 0$)$ surfaces after different periods in contact with solutions with $\left[\mathrm{Pb}_{\mathrm{aq}}\right]_{\text {initial }}=1000$. Due to its perfect cleavage, gypsum $\left(\begin{array}{lll}0 & 1 & 0\end{array}\right)$ surfaces are usually very flat (dark areas in the SEM images), showing large terraces bounded by macrosteps (brighter alignments across the surface). After just 1 min in contact with the Pb-bearing solution, small rhombusshaped crystals could be distinguished scattered on the gypsum $\left(\begin{array}{lll}0 & 1 & 0\end{array}\right)$ surface. The number of these crystals per unit area rapidly increased with time to reach a maximum after 30 min (compare Fig. $4 a-c$ ). The density of crystals did not further increase for longer interaction periods. As a result the gypsum surface was covered by a discontinuous layer comprised of the rhombus-shaped crystals (Fig. 4b) in a random orientation with respect to the substrate (Fig. 4d). EDX analyses of the newly-formed crystals showed that they are mainly composed of $\mathrm{S}, \mathrm{O}$ and $\mathrm{Pb}$. Both the composition and the morphology (Hartman and Strom, 1989) of these crystals are consistent with those of anglesite, which was confirmed by XRD analysis carried out on the surface of the gypsum substrate.

In the experiments carried out using $\left[\mathrm{Pb}_{\mathrm{aq}}\right]_{\text {initial }}=100 \mathrm{mg} / \mathrm{L}$ solutions similar results have been obtained. In this case, anglesite crystals can also be observed on the surface of gypsum after just a $1 \mathrm{~min}$ in contact with the solution (Fig. 5). However, the density of anglesite crystals that form on the gypsum substrate is considerably smaller than in the case of $\left[\mathrm{Pb}_{\mathrm{aq}}\right]_{\text {initial }}=1000 \mathrm{mg} / \mathrm{L}$ solution when similar periods of interaction are considered.

Finally, when gypsum crystals where maintained in contact with solutions with $\left[\mathrm{Pb}_{\mathrm{aq}}\right]_{\text {initial }}=10 \mathrm{mg} / \mathrm{L}$, no anglesite crystal formation was evidenced by SEM imaging of the gypsum surfaces, irrespective the length of the interaction time considered.

\subsection{2. $p$-RBS measurements}

The p-RBS spectra are depicted in Fig. 6. The upper 3 spectra correspond to gypsum $\left(\begin{array}{lll}0 & 1 & 0\end{array}\right)$ crystal surfaces interacted with $\left[\mathrm{Pb}_{\mathrm{aq}}\right]_{\text {initial }}=10 \mathrm{mg} / \mathrm{L}$ for $30 \mathrm{~min}$ (Fig. 6a), 3 days (Fig. 6b) and 1 week (Fig. 6c), while the bottom (Fig. 6d-f) represent crystal surfaces interacted with $\left[\mathrm{Pb}_{\mathrm{aq}}\right]_{\text {initial }}=100 \mathrm{mg} / \mathrm{L}$ for the same time intervals. Table 1 summarizes the p-RBS results according to the SIMNRA simulations. Atomic concentrations shown in Table 1 correspond to the outermost layer of the gypsum crystals exposed to the Pb-bearing solutions. As can be seen, in all the p-RBS analyses $\mathrm{O}$ appears in excess with respect to gypsum stoichiometry. This $\mathrm{O}$ excess can be attributed to both additional $\mathrm{H}_{2} \mathrm{O}$ and minor amounts of hydrated $\mathrm{Ca}$ and $\mathrm{Pb}$ sulfate compounds of uncertain crystallinity, chemisorbed and/or physisorbed onto the surface layer. Therefore, the possibility that different $\mathrm{Pb}$-sorption mechanisms (anglesite surface precipitation, hydrated Pb-rich compounds adsorption, etc.) were simultaneously operating, was taken into consideration when calculating the thickness of the $\mathrm{Pb}$-affected surface layer. This calculation yielded a maximum thickness of $\sim 7 \mu \mathrm{m}$.

As can be observed, in the case of $\left[\mathrm{Pb}_{\mathrm{aq}}\right]_{\text {initial }}=10 \mathrm{mg} / \mathrm{L}$ solution, after 30 min interaction no $\mathrm{Pb}$ is detected in the near-surface layers of the material. This result agrees with the data obtained through other techniques (SEM imaging and XRD), as well as with the 

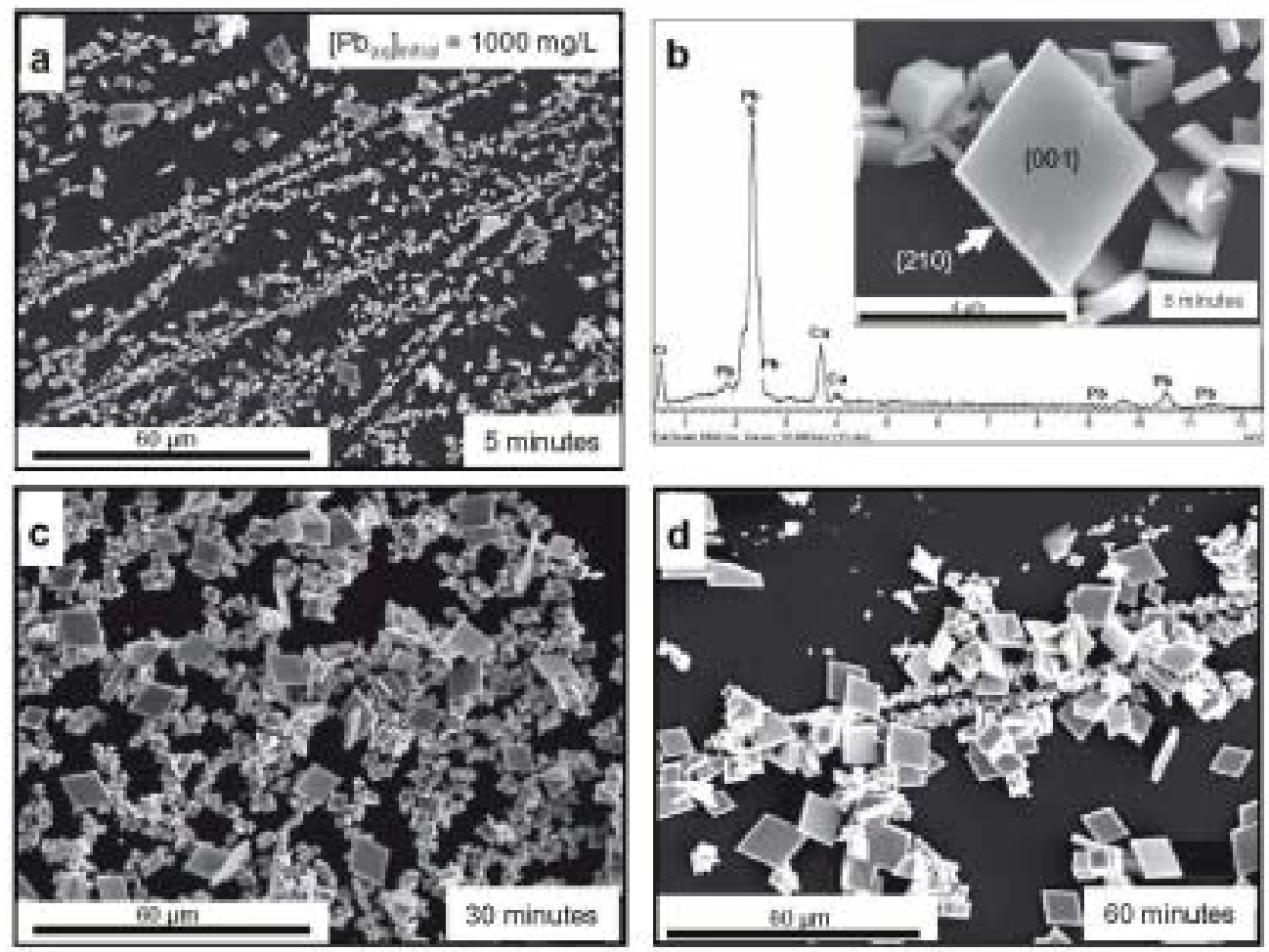

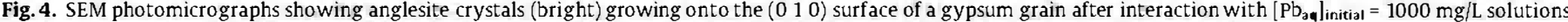
The images correspond to different periods of interaction ranging from 5 to $60 \mathrm{~min}$. (b) Shows an EDX analysis of an anglesite crystal.
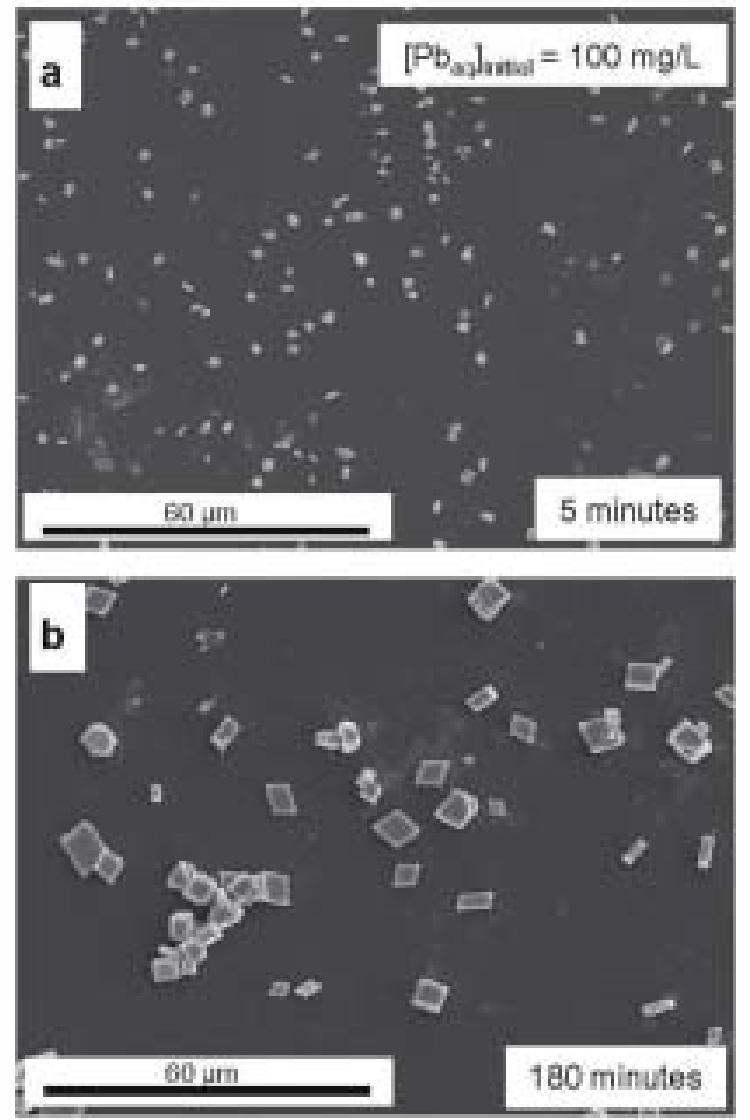

Fig. 5. SEM photomicrographs of the $\left(\begin{array}{lll}0 & 1 & 0\end{array}\right)$ surface of a gypsum grain obtained after 5 and $180 \mathrm{~min}$ of reaction with $\left[\mathrm{Pb}_{\mathrm{a}}\right]_{\text {initial }}=100 \mathrm{mg} / \mathrm{L}$ solutions. macroscopic analytical results. However, an evident Pb-rich layer, not found using other methods, is detected in the samples corresponding to 3 days and 1 week of interaction. In the case of $\left[\mathrm{Pb}_{\mathrm{aq}}\right]_{\text {initial }}=100 \mathrm{mg} / \mathrm{L}$ solution, a durable and relatively thick $\mathrm{Pb}$ bearing layer is detected in all the samples studied (see Fig. 6d-f and Table 1). This layer is present even when a short interaction period is considered ( $30 \mathrm{~min}$ ) and at any time it is thicker than in the samples corresponding to the $\left[\mathrm{Pb}_{\mathrm{aq}}\right]_{\text {initial }}=10 \mathrm{mg} / \mathrm{L}$ solution. These results are in good agreement with both the SEM observations and the results obtained in the batch reactor experiments.

\section{Discussion}

The experimental results indicate that the removal of $\mathrm{Pb}$ from an aqueous solution in contact with gypsum fragments occurs through at least two different sorption mechanisms, adsorption and precipitation, taking place at the gypsum-aqueous solution interface. The predominance of a specific mechanism depends on the $\left[\mathrm{Pb}_{\mathrm{aq}}\right]_{\text {initial. }}$. Thus, the experimental data in Figs. 1 and 3 show that, when the initial concentration of $\mathrm{Pb}$ in the aqueous solutions is high or moderate $\left(\left[\mathrm{Pb} \mathrm{aq}_{\text {initial }}=1000\right.\right.$ and $100 \mathrm{mg} / \mathrm{L}$ respectively $)$, the sorption of $\mathrm{Pb}$ by gypsum occurs very rapidly. In contrast, when solutions with a low initial concentration of $\mathrm{Pb}\left(\left[\mathrm{Pb}_{\mathrm{aq}}\right]_{\text {initial }}=10 \mathrm{mg} / \mathrm{L}\right)$ are used, the removal of this metal occurs very slowly. The processes involved in each case need to be discussed separately. However, in order to do that, it is necessary to gain information on the evolution of the saturation indices (SI) of the aqueous solutions considered with respect to the solid phases involved during the progression of the reaction. This information enabled the definition of the driving forces that operate in the system in each case. Both the speciation of the aqueous solution and its saturation indices for gypsum and anglesite were calculated for different interaction times by applying the geochemical code and database PHREEQC (Parkhurst 
Energy $[\mathrm{KeV}]$

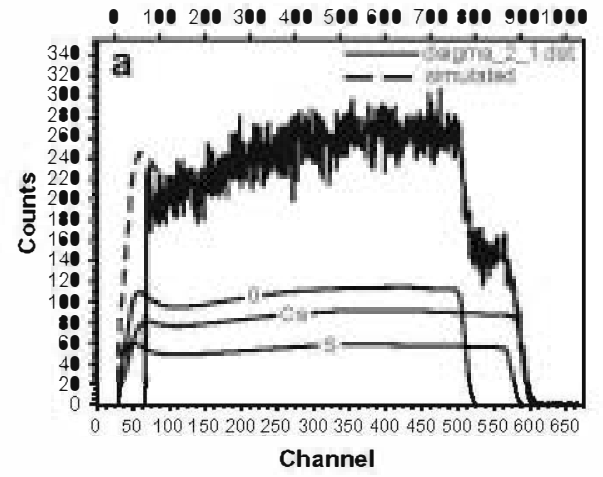

Energy $[\mathrm{KeV}]$

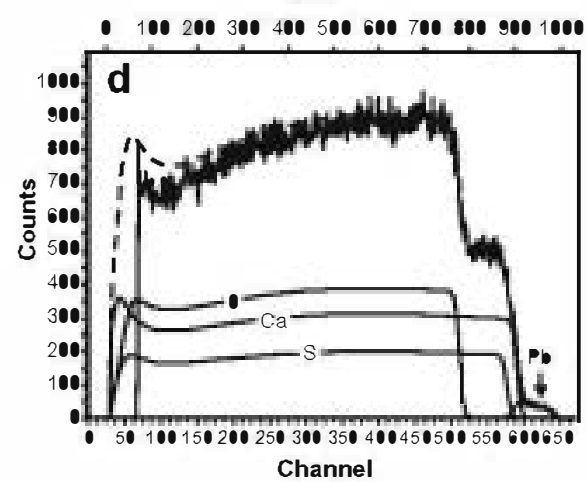

Energy [KeV]

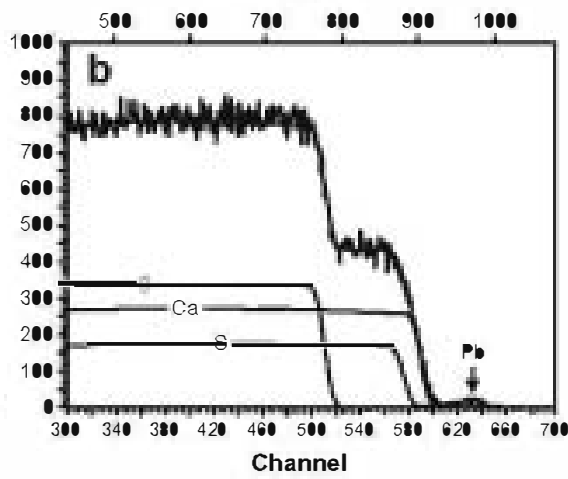

Energy $[\mathrm{KeV}]$

- 1002003004005006007008009001000

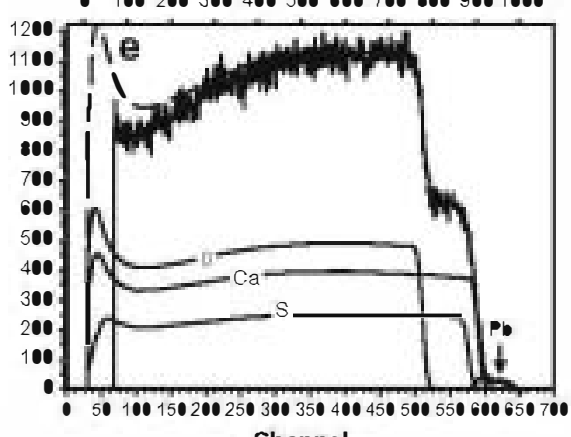

Energy $[\mathrm{KeV}]$

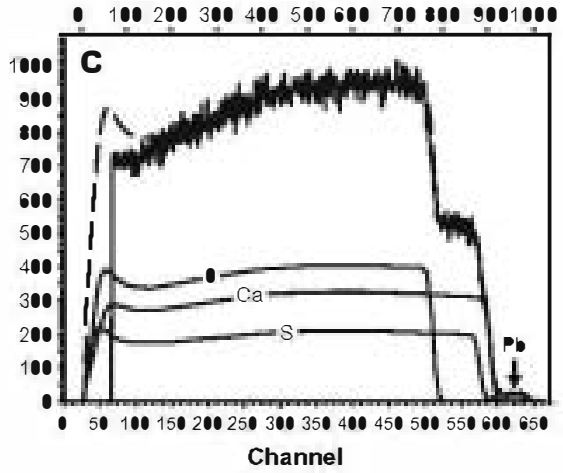

Energy [KeV]

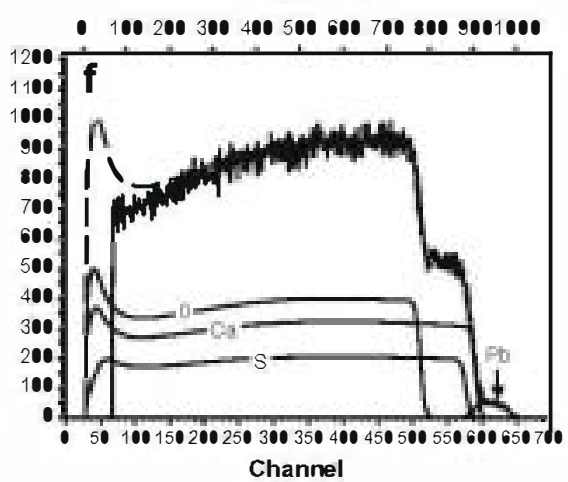

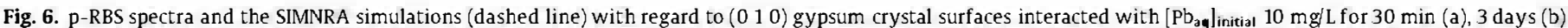

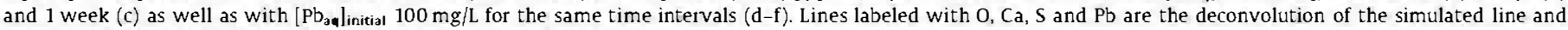
represent depth-diswibution of these elements in near-surface layers.

Table 1

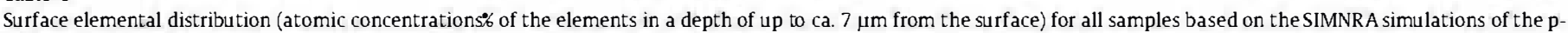
RBS spectra (Fig. 4).

\begin{tabular}{|c|c|c|c|c|c|c|}
\hline Sample & $\begin{array}{l}{\left[\mathrm{Pb}_{\text {aq }}\right]_{\text {initial }} 10 \mathrm{mg} / \mathrm{L}} \\
30 \mathrm{~min}\end{array}$ & $\begin{array}{l}{\left[\mathrm{Pb}_{\text {aa }}\right]_{\text {initial }} 10 \mathrm{mg} / \mathrm{L} \text {, }} \\
3 \text { days }\end{array}$ & $\begin{array}{l}{\left[\mathrm{Pb}_{\text {aq }}\right]_{\text {initial }} 10 \mathrm{mg} / \mathrm{L}} \\
1 \text { week }\end{array}$ & $\begin{array}{l}{\left[\mathrm{Pb}_{\mathrm{aq}}\right]_{\text {initial }} 100 \mathrm{mg} / \mathrm{L}} \\
30 \mathrm{~min}\end{array}$ & $\begin{array}{l}{\left[\mathrm{Pb}_{\text {aq }}\right]_{\text {initial }} 100 \mathrm{mg} / \mathrm{L} \text {, }} \\
3 \text { days }\end{array}$ & $\begin{array}{l}{\left[\mathrm{Pb}_{\text {aq }}\right]_{\text {initial }} 100 \mathrm{mg} / \mathrm{L} \text {, }} \\
1 \text { week }\end{array}$ \\
\hline $\mathrm{Pb}$ atoms\% & - & 0.03 & 0.03 & 0.09 & 0.06 & 0.09 \\
\hline Ca atoms\% & 10 & 10 & 10 & 10 & 10 & 10 \\
\hline $\mathrm{S}$ atoms\% & 10 & 10 & 10 & 10 & 10 & 10 \\
\hline $\mathrm{O}$ atoms\% & 80 & 79.97 & 79.97 & 79.91 & 79.94 & 79.91 \\
\hline
\end{tabular}

and Appelo, 1999). The input data corresponded to the information reported by the chemical analyses of the aqueous solutions and the measured pHs. The saturation indices (SI) for gypsum and anglesite, $\mathrm{SI}_{\text {gypsum }}$ and $\mathrm{SI}_{\text {anglesite }}$ are defined as $\log \left(\left(\mathrm{SO}_{4}^{2-}\right)\left(\mathrm{Ca}^{2+}\right)\left(\mathrm{H}_{2} \mathrm{O}\right)^{2} / K_{\mathrm{Sp}_{\text {gypsum }}}\right)$ and $\log \left(\left(\mathrm{SO}_{4}^{2-}\right)\left(\mathrm{Pb}^{2+}\right) / K_{\text {sp }_{\text {anglesite }}}\right)$, respectively; where $\left(\mathrm{SO}_{4}^{2-}\right),\left(\mathrm{Ca}^{2+}\right),\left(\mathrm{Pb}^{2+}\right)$ and $\left(\mathrm{H}_{2} \mathrm{O}\right)$ are the activities of $\left(\mathrm{SO}_{4}^{2-}\right), \mathrm{Ca}^{2+}, \mathrm{Pb}^{2+}$ and water $(=1)$ in the aqueous solution, respectively. $\mathrm{SI}=0$ reflects equilibrium, $\mathrm{SI}<0$, undersaturation and $\mathrm{SI}>0$ supersaturation. Other possible solid phases, such as anhydrite $\left(\mathrm{CaSO}_{4}\right)$, plattnerite $\left(\mathrm{PbO}_{2}\right)$ and $\mathrm{Pb}(\mathrm{OH})_{2}$ were not taken into consideration because the solution was always undersaturated with respect to these phases. At the start of the experiments, the aqueous solution was free of $\mathrm{SO}_{4}^{2-}$ and $\mathrm{Ca}$ and, consequently, undersaturated $(\mathrm{SI}<0)$ with respect to gypsum and anglesite. Fig. 7a shows the evolution of the SI for gypsum and anglesite when a solution with $\left[\mathrm{Pb}_{\mathrm{aq}}\right]_{\text {initial }}=1000 \mathrm{mg} / \mathrm{L}$ was used. The rapid release of $\mathrm{Ca}$ and $\mathrm{SO}_{4}^{2-}$ to the aqueous solution (see Fig. 3), which is a consequence of the relatively fast dissolution of gypsum, led to a very rapid increase of the SI for both anglesite and gypsum. As a result, the fluid became supersaturated with respect to anglesite, reaching a maximum $\left(\mathrm{SI}_{\text {anglesite }}=2.22\right.$ ) after just $1 \mathrm{~min}$. Beyond this point, the SI for anglesite $\mathrm{SI}_{\text {anglesite }}$ underwent a rapid drop to approach a limiting value $\approx 0$, i.e. the saturation state, after 30 min interaction, which remained approximately constant for longer reaction times. In parallel, $\mathrm{SI}_{\text {gypsum }}$ also increased from the undersaturation stage to reach saturation after $60 \mathrm{~min}$.

The evolution of the SI with respect to gypsum and anglesite for $\left[\mathrm{Pb}_{\mathrm{aq}}\right]_{\text {initial }}=100$ is shown in Fig. 7b. As can be observed, such evolution is very similar to that described above for $[\mathrm{Pb}]_{\text {initial }}=$ $1000 \mathrm{mg} / \mathrm{L}$ (Fig. 7a): in this case the maximum SI anglesite reached was significantly lower $\left(\mathrm{SI}_{\text {anglesite }}=1.02\right)$ compared to the value attained in the previous case ( $\mathrm{SI}_{\text {anglesite }}=2.22$ ). The time elapsed when such a maximum was reached, 1 min, was identical in both cases.

The evolution of the SI with respect to gypsum and anglesite when the $\left.\left[\mathrm{Pb}_{\mathrm{aq}}\right]_{\text {initial }}=10 \mathrm{mg} / \mathrm{L}\right)$ is shown in Fig. 7c. The behavior observed in this case contrasts with that described above for solutions with higher $\mathrm{Pb}$ concentrations. Although $\mathrm{SI}_{\text {anglesite }}$ also in- 

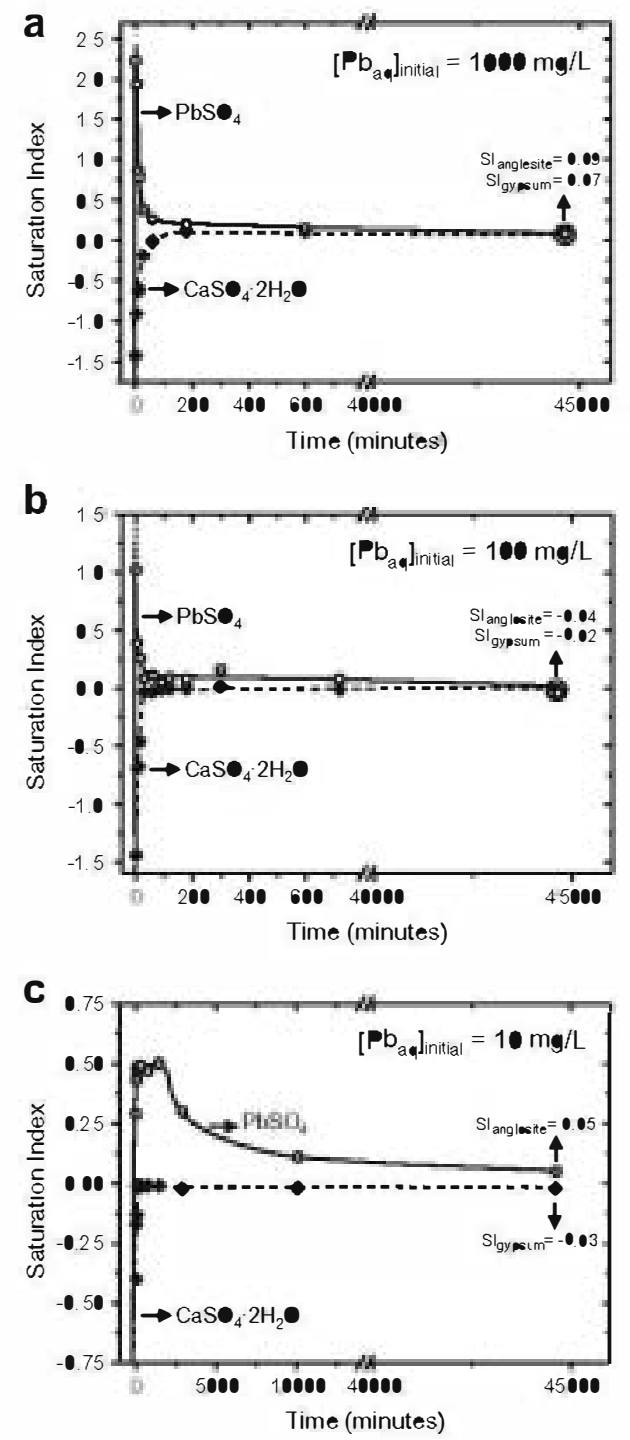

Fig. 7. Evolution of the saturation index of the experimental solutions with respect to anglesite and gypsum as a function of time. The data correspond to the interaction of gypsum fragments with Pb-bearing solutions (a) $1000 \mathrm{mg} / \mathrm{L}$, (b) $100 \mathrm{mg} / \mathrm{L}$, and (c) $10 \mathrm{mg} / \mathrm{L}[\mathrm{Pb}]$.

creases rapidly, such an increase is much more limited than in the previous cases and occurs at a much lower rate. The maximum $\mathrm{SI}_{\text {anglesite }}$ was reached after $120 \mathrm{~min}$ in this case and its value $\sim 0.5$. Therefore, when $\left[\mathrm{Pb}_{\mathrm{aq}}\right]_{\text {initial }}=10 \mathrm{mg} / \mathrm{L}$ is used, the solution only becomes slightly supersaturated for anglesite. Moreover, this maximum value remained constant for $\sim 24 \mathrm{~h}$, and decreased very slowly beyond this point. Finally, the solution reached a $\mathrm{SI}_{\text {anglesite }}$ value close to saturation after 1 month. In contrast, the saturation index with respect to gypsum evolved similarly to that observed in the experiments with $\left[\mathrm{Pb}_{\mathrm{aq}}\right]_{\text {initial }}$ equal to 1000 and $100 \mathrm{mg} / \mathrm{L}$, quickly approaching zero from a state of undersaturation.

The fact that the evolution of the $\mathrm{SI}_{\text {gypsum }}$ was very similar in all the experiments carried out, whereas $\mathrm{SI}_{\text {anglesite }}$ evolved very differently depending on whether the $\left[\mathrm{Pb}_{\mathrm{aq}}\right]_{\text {initial }}$ was low or high to moderate, further points towards the existence of at least two different mechanisms (bulk/surface precipitation and adsorption) for the removal of $\mathrm{Pb}$ from solution. One mechanism (bulk/surface precipitation) was observed to predominantly operate when $\left[\mathrm{Pb}_{\mathrm{aq}}\right]_{\text {initial }}$ is equal to 1000 and $100 \mathrm{mg} / \mathrm{L}$. In the case of $\left[\mathrm{Pb} \mathrm{aq}_{\text {initial }}=\right.$ $10 \mathrm{mg} / \mathrm{L}$, adsorption was most probably the main mechanism although surface precipitation could also occur. However, no evi- dence of Pb-absorption onto the gypsum substrate has been observed in any of the experiments carried out.

\subsection{Gypsum interaction with aqueous solutions containing high to moderate $\mathrm{Pb}$ concentrations}

When highly to moderately $\mathrm{Pb}$ concentrated solutions $\left(\left[\mathrm{Pb}_{\mathrm{aq}}\right]_{\text {initial }}=\right.$ 100 and $1000 \mathrm{mg} / \mathrm{L}$ ) are put in contact with gypsum, the removal of this pollutant is the direct consequence of the precipitation of anglesite, which immobilizes this metal in its structure. Two processes are involved in the removal of $\mathrm{Pb}$ under these conditions. First, the dissolution of gypsum releases $\mathrm{Ca}^{2+}$ and $\mathrm{SO}_{4}^{2-}$ ions to the fluid. As a result, the system becomes highly supersaturated with respect to anglesite. Second, the reaction between the dissolved $\mathrm{SO}_{4}^{2-}$ and the $\mathrm{Pb}_{\mathrm{aq}}^{2+}$ ions leads to the formation of $\mathrm{PbSO}_{4(\mathrm{~s})}$ as described in Eqs. (1) and (2). The dissolution of gypsum and the crystallization of anglesite are coupled processes. Such a coupling explains the subsequent evolution of the SI for gypsum and anglesite (Fig. 7). Thus, after 120-180 min the aqueous solution is in equilibrium with gypsum. At this stage, the solution is still slightly supersaturated with respect to anglesite. Beyond this point, the coupling between gypsum dissolution and anglesite precipitation causes a slowdown of gypsum dissolution, thus releasing $\mathrm{SO}_{4}^{2-}$ ions at a slower rate, concomitant with a progressive drop of the precipitation rate of anglesite. As a result, $\mathrm{SI}_{\text {anglesite }}$ evolves slowly to approach equilibrium after 30 days.

Similar couplings have been extensively described for other aqueous solution-mineral systems in which the dissolution of a parent mineral is the starting point for the formation of a new solid product, which commonly is a sparingly soluble salt (Godelitsas et al., 2003b; Prieto et al., 2003; Rodríguez-Blanco et al., 2007; Fernández-Díaz et al., 2009). Moreover, several experimental studies have explored the capability of gypsum surfaces to remove contaminants. For example, Rodríguez-Blanco et al. (2007) studied the interaction of gypsum with As-bearing solutions and found that, as gypsum dissolves, pharmacolite $\left(\mathrm{CaHAsO}_{4} \cdot 2 \mathrm{H}_{2} \mathrm{O}\right)$ is formed and incorporates As into its structure thus removing As from solution. However, the dissolution of gypsum and precipitation of pharmacolite quickly becomes a limited method for sequestering As. The results of Rodríguez-Blanco et al. (2007) contrast with the results of this study. Under the conditions of this study, gypsum significantly removes $\mathrm{Pb}$ from solution via a combination of dissolution of gypsum and (co)precipitation of anglesite. Prieto et al. (2003) demonstrated that the existence of crystallographic relationships between sorbant and sorbate is a critical factor controlling the capability of a substrate to remove a specific pollutant as a result of (co)precipitation. When such crystallographic relationships exist, the solid that incorporates the pollutant into its structure forms a homogeneous precipitate of a certain number of layers. This overgrowth rapidly covers the substrate against further interaction with the aqueous solution, which leads to the complete cessation of the removal process. In the case studied by Rodríguez-Blanco et al. (2007), the limited capability of gypsum to remove As is a direct consequence of the similarity between the structures of gypsum and pharmacolite. After a small amount of As is removed from solution, pharmacolite forms an oriented overgrowth on gypsum, which rapidly covers the gypsum surface and prevents further dissolution when only a very small amount of As had been removed from the solution. Under the conditions of the present experiment, no epitaxial relationship exists between the sorbate (anglesite) and the sorbent (gypsum), as is evidenced from imaging as shown in Figs. 4 and 5. Moreover, the overgrowth layer of anglesite never completely covered the surface of gypsum. As a consequence, the contact between the aqueous solution and the gypsum surface was maintained, guaranteeing the progress of the dissolution-crystallization process with time. 
4.2. Gypsum interaction with aqueous solutions containing low $\mathrm{Pb}$ concentrations

As discussed in previous sections, the behavior observed in the experiments carried out using the lowest $\mathrm{Pb}$ concentration $\left(\left[\mathrm{Pb}_{\mathrm{aq}}\right]_{\text {initial }}=10 \mathrm{mg} / \mathrm{L}\right)$ significantly differed from the behavior observed when solutions with higher $\mathrm{Pb}$ concentrations were used. In this case, no decrease in the concentration of $\mathrm{Pb}$ in the solution was detected during the first $24 \mathrm{~h}$, although the solution quickly became supersaturated with respect to anglesite, reaching the maximum $\mathrm{SI}_{\mathrm{anglesite}}$ after $120 \mathrm{~min}$. However, the value of the maximum $\mathrm{SI}_{\mathrm{anglesite}}$ was relatively low $(\sim 0.5)$. Under these conditions, the solution can remain metastable, without any precipitation of anglesite occurring in the system. Such a metastable stage lasted the whole duration of the experiments, since no anglesite crystals were detected on the surface of gypsum even after very long reaction times. In this particular case, the higher $\left[\mathrm{Ca}_{\mathrm{aq}}\right] /\left[\mathrm{Pb}_{\mathrm{aq}}\right]$ ratio in the solution can contribute to prolong metastability. Certain cations have an inhibitory effect on the crystallization of sulfates with a barite-type structure (Astilleros et al., 2003), which is the case for anglesite. This effect has been related to the large difference between the ionic radii of the cations in the structure of these sulfates $\left(\mathrm{Ba}^{2+}, \mathrm{Sr}^{2+}, \mathrm{Pb}^{2+}\right.$ ) and those present in the aqueous solution. The ionic radii of $\mathrm{Pb}^{2+}$ and $\mathrm{Ca}^{2+}$ are 1.49 and $1.34 \AA$, respectively, for [12]coordination, (Shannon, 1976). Therefore, their difference in radii is $\approx 11 \%$, which must preclude the incorporation of $\mathrm{Ca}^{2+}$ into the crystal lattice of anglesite during growth. This inhibitory effect must become more significant as the $\left[\mathrm{Ca}_{\mathrm{aq}}\right] /\left[\mathrm{Pb}_{\mathrm{aq}}\right]$ ratio becomes higher. Fig. 8 shows the variation of the $\left[\mathrm{Ca}_{\mathrm{aq}}\right] /\left[\mathrm{Pb}_{\mathrm{aq}}\right]$ ratio with time for $\left[\mathrm{Pb}_{\mathrm{aq}}\right]_{\text {initial }}=1000,100$ and $10 \mathrm{mg} / \mathrm{L}$. Since the evolution of the $\mathrm{Pb}$ content in the solution over time for $\left[\mathrm{Pb}_{\mathrm{aq}}\right]_{\text {initial }} 100 \mathrm{mg} /$ $\mathrm{L}$ follows a similar trend to that shown for $\left[\mathrm{Pb}_{\mathrm{aq}}\right]_{\text {initial }}=1000$, the behavior is very similar. The $\left[\mathrm{Ca}_{\mathrm{aq}}\right] /\left[\mathrm{Pb}_{\mathrm{aq}}\right]$ ratio increases with time as a consequence of $\mathrm{Pb}$ removal and gypsum dissolution, which releases $\mathrm{Ca}$ to the solution. As can be observed in the plot in Fig. 8, at the beginning of the experiment ( 1 min of reaction) such a ratio is approximately two and one orders of magnitude higher in the experiments carried out with $\left[\mathrm{Pb}_{\mathrm{aq}}\right]_{\text {initial }}=10 \mathrm{mg} / \mathrm{L}$ than in the experiments with $\left[\mathrm{Pb}_{\text {aq }}\right]_{\text {initial }}=1000 \mathrm{mg} / \mathrm{L}$ and $1000 \mathrm{mg} / \mathrm{L}$, respectively. This factor, in addition to the much lower supersaturation of the solution with respect to anglesite, can explain why no anglesite formed when solutions $\left[\mathrm{Pb}_{\mathrm{aq}}\right]_{\text {initial }}=10 \mathrm{mg} / \mathrm{L}$ were used. In this case, $\mathrm{SI}_{\text {anglesite }}$ progressively decreased after 1 day. This points to the removal of $\mathrm{Pb}$ by adsorption on the gypsum surface. This mechanism can only become effective once the dissolution of gypsum has completely stopped, which is consistent with the observations since the system had already reached equilibrium with respect to gypsum when the $\mathrm{SI}_{\text {anglesite }}$ started to decrease in this case. This conclusion is further supported by the results of the p-RBS measurements.

These results indicate that the $\mathrm{O}, \mathrm{Ca}$ and $\mathrm{S}$ contents in the substrate are roughly stable for all interacted gypsum crystals, which implies that there is no incorporation of $\mathrm{Pb}$ ions beneath the $\mathrm{Pb}$ rich layers. Therefore, the formation of a distinct interface on a nanoscale must have occurred between a Pb-rich layer and the $\mathrm{CaSO}_{4} \cdot 2 \mathrm{H}_{2} \mathrm{O}$ substrate. As indicated in the Results section, the element distribution shown in Table 1 corresponds to a surface layer of $\sim 7 \mu \mathrm{m}$. The thickness of this layer was calculated considering that $\mathrm{Pb}$ might be sorbed onto gypsum surfaces through different mechanisms, including surface precipitation of anglesite, as well as chemisorption and/or physisorption of $\mathrm{Pb}$-rich species.

It is concluded that at low $\mathrm{Pb}$ concentration $\left(\left[\mathrm{Pb}_{\mathrm{aq}}\right]_{\text {initial }}=\right.$ $10 \mathrm{mg} / \mathrm{L}$ ) adsorption occurred from the beginning of the interaction up to approximately 3 days. Then, the formation of Pb-sulfate layers occurred (crystal overgrowth or surface precipitation). The same process took place extensively in all cases of higher $\mathrm{Pb}$
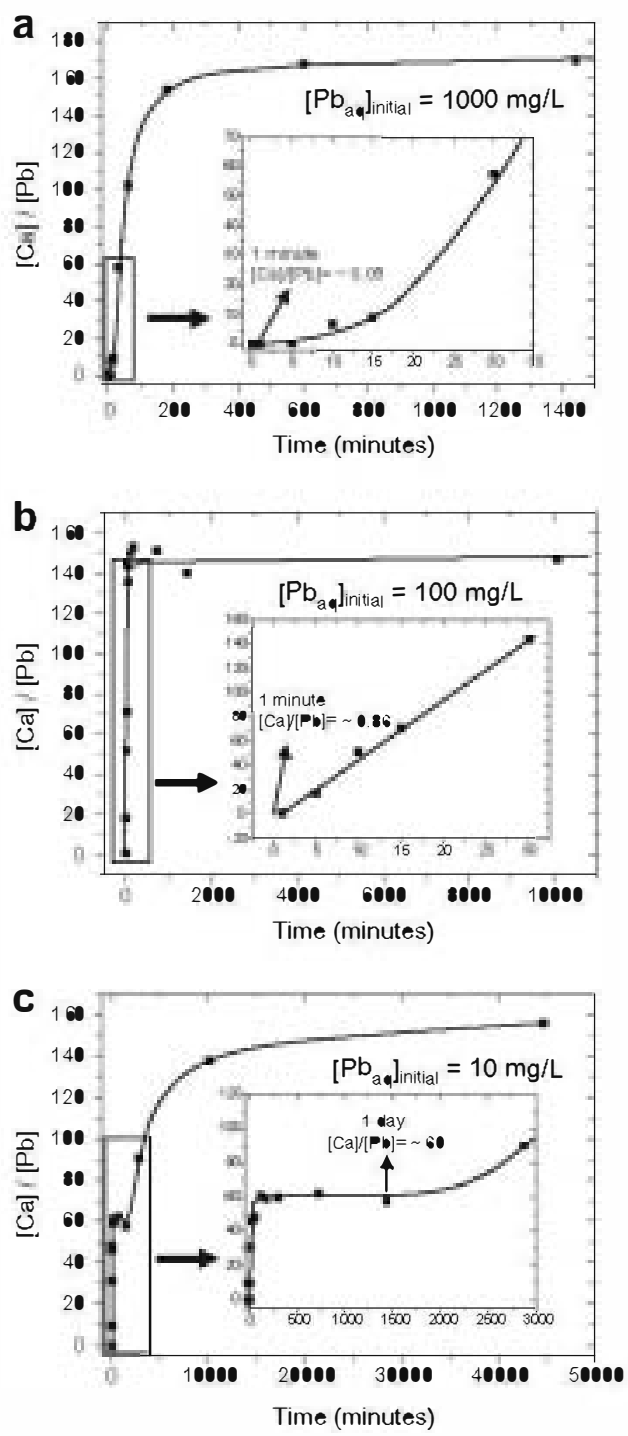

Fig. 8. Evolution of the $[\mathrm{Ca}] /[\mathrm{Pb}]$ of the experimental solutions as a function of time. The data correspond to the interaction of gypsum fragments with $\mathrm{Pb}$-bearing solutions (a) $1000 \mathrm{mg} / \mathrm{L}$, (b) $100 \mathrm{mg} / \mathrm{L}$ and (c) $10 \mathrm{mg} / \mathrm{L}$. Inserted graphics are a detail of the framed areas.

concentration $\left(\left[\mathrm{Pb}_{\mathrm{aq}}\right]_{\text {initial }}=100 \mathrm{mg} / \mathrm{L}\right)$. On the other hand, "surface co-precipitation" (involvement of $\mathrm{Ca}$ ions derived from the substrate due to dissolution into the Pb-sulfate layers) can not be excluded. However, there is no indication for absorption of $\mathrm{Pb}$ ions (metal incorporation) beneath the Pb-sulfate layers formed on gypsum. This is evidenced from the isolated $\mathrm{Pb}$ peaks in the p-RBS spectra of Fig. 6, which points to a sharp interface between the Pb-rich layer and the gypsum substrate.

\section{Conclusions}

Under the conditions of these experiments, $\mathrm{Pb}$ reacts easily with gypsum in aqueous environments. Both microscopic and macroscopic observations indicate that $\mathrm{Pb}$ is incorporated onto gypsum by surface precipitation of anglesite crystals through a simultaneous dissolution-precipitation process when the initial concentration of $\mathrm{Pb}$ in the solution ranges from 100 to $1000 \mathrm{mg} / \mathrm{L}$. As a consequence, the concentration of $\mathrm{Pb}$ in the aqueous solution declines to reach values controlled by the relatively low solubility of anglesite. Although the uptake capacity of gypsum is limited 
by its solubility product, the overall rate of the process depends on both the growth rate of the product phase and the dissolution rate of the starting phase. The high solubility of gypsum ensures a rapid development of the dissolution process. Therefore, the kinetics of the coupled process is basically controlled by the anglesite growth rate. Moreover, the fact that the precipitate grows randomly onto the gypsum surface due to the lack of structural relationships between sorbate (anglesite) and sorbent (gypsum) favours the development of the process.

In summary, gypsum appears to be a good sorbent for $\mathrm{Pb}$ in environments where this metal reaches toxic concentrations. Moreover, natural attenuation of $\mathrm{Pb}$ is likely to occur through anglesite precipitation in aqueous environments, especially in those related to acid main drainage, where $\mathrm{SO}_{4}^{2-}$ anions are continuously provided as a result of sulfide oxidation.

\section{Acknowledgments}

This work has been financially supported by the Spanish government under Contract CGL2007-65523-C02-01). Financial support has also been provided by the Research Group 910148 (UCM-Comunidad de Madrid, Spain). The Complutense University of Madrid has also provided financial support for Jose Manuel Astilleros through a travel grant. We sincerely thank the Microscopy Centre and the X-ray Diffraction Central Service of the Complutense University of Madrid for technical assistance. We also thank two anonymous reviewers for providing very useful suggestions for improving the manuscript.

\section{References}

Astilleros, J.M., Pina, C.M., Fernández-Díaz, L., Putnis, A., 2003. Nanoscale growth of solids crystallising from multicomponent aqueous solutions. Surf. Sci. 545 L767-L773.

Bigham, J.M., Nordstrom, D.K., 2000. Iron and aluminum hydroxysulfates from acid sulfate waters. In: Alpers, C.N., Jambor, J.L., Nordstrom, D.K (Eds.), Sulfate Minerals - Crystallography, Geochemistry, and Environmental Significance. Mineralogical Society of America/Geochemical Society, Washington, DC, pp. 351-403.

Blowes, D.W., Ptacek, C.J., Jambor, J.L., Weisener, C.G., 2005. The geochemistry of acid mine drainage. In: Sherwood Lollar, B. (Ed.), Environmental Geochemistry. Holland, H.D., Turekian, KK (Exec. Eds.), Treatise on Geochemistry, vol. 9. Elsevier-Pergamon, Oxford, pp. 149-204 (chapter 5)

Conca, J.L., Wright, J., 2001. Treatment of Metal-contaminated Leachates Unilizing Fish Bones and Fish Hard Parts. United States Patent, Number 6217,775.

Conca, J.L., Wright, J., 2006. An apatite ${ }^{\mathrm{TM}}$ permeable reactive barrier to remediate groundwater containing $\mathrm{Zn}, \mathrm{Pb}$ and $\mathrm{Cd}$. Appl. Geochem. 21, 1288-1300.

Cortina, J.-L., Lagreca, I., De Pablo, J., Cama, J., Ayora, C., 2003. Passive in situ remediation of metal-polluted water with caustic magnesia: evidence from column experiments. Environ. Sci. Technol. 37, 1971-1977.
Fernández-Díaz, L., Pina, C.M., Astilleros, J.M., Sánchez-Pastor, N., 2009. The carbonatation of gypsum: pathways and pseudomorphs formation. Am. Mineral. 94, 1223-1234.

Godelitsas, A., Astilleros, J.M., Hallam, K, Harissopoulos, S., Putnis, A., 2003a Interaction of calcium carbonates with lead in aqueous solutions. Environ. Sci. Technol. 37, 3351-3360.

Godelitsas, A., Astilleros, J.M., Hallam, K, Löns, J., Putnis, A., 2003b. Microscopic and specroscopic investigation of the calcite surface interacted with mercury (II) acetate aqueous solutions. Mineral. Mag. 67, 1196-1204.

Hartman, P., Strom, C.S., 1989. Structural morphology of crystals with the barite $\left(\mathrm{BaSO}_{4}\right)$ structure: a revision and extension. J. Crystal Growth 97, 502-512.

Lin, Z., 1997. Mineralogical and chemical characterization of wastes from the sulphuric acid industry in Falun Sweden. Environ. Geol. 30, 152-162.

Lin, Z., Herbert Jr., R.B., 1997. Heavy metal retention in secondary precipitates from a mine rock dump and underlaying soil, Dalarna, Sweden. Environ. Geol. 33, 112.

Lin, Z., Comet, B., Qvarfort, U., Herbert, R., 1995. The chemical and mineralogical behaviour of $\mathrm{Pb}$ in shooting range soils from central Sweden. Environ. Pollut. 89 303-309.

Lottermoser, B., 2007. Mine Wastes: Characterization, Treament and Environmental Impacts, second ed. Berlin Heilderberg, Springer-Verlag.

Lower, S.K., Maurice, P.A., Traina, S.J., 1998a. Simultaneous dissolution of hydroxylapatite and precipitation of hydroxypyromorphite: direct evidence of homogeneous nucleation. Geochim. Cosmochim. Acta 62, 1773-1780.

Lower, S.K, Maurice, P.A., Traina, S.J., Carlson, E.H., 1998b. Aqueous Pb sorption by hydroxylapatite: applications of atomic force microscopy to dissolution, nucleation, and growth studies. Am. Mineral. 83, 147-158.

Ma, Q.Y., Traina, S.J., Logan, T.J., Ryan, J.A., 1993. In situ lead immobilization by apatite. Environ. Sci. Technol. 27, 1803-1810.

Martin, W.A., Larson, S.L., Felt, D.R., Wright, J., Griggs, C.S., Thompson, M., Conca, J.L. Nestler, C.C., 2008. The effect of organics on lead sorption onto apatite II ${ }^{\mathrm{m}}$. Appl. Geochem. 23, 34-43.

Mayer, M., 2002. Computer Code SIMNRA, Version 5.0, Institut für Plasmaphysik, Garching.

Nriagu, J.O., Pacyna, J.M., 1988. Quantitative assessment of worldwide contamination of air, water and soils by trace metals. Nature 333, 134-139.

Parkhurst, D.L., Appelo, C.A.J., 1999. User's Guide to PHREEQC (Version 2) - A Computer Program for Speciation, Batch-reaction, One-dimensional Transport and Inverse Geochemical Calculations. US Geol. Surv. Water-Resour. Invest. Rep. pp. 99-4259.

Prieto, M., Cubillas, P., Fernández-González, A., 2003. Uptake of dissolved Cd by biogenic and abiogenic aragonite: a comparison with sorption onto calcite. Geochim. Cosmochim. Acta 67, 3859-3869.

Rodríguez-Blanco, J.D., Jimênez, A., Prieto, M., 2007. Oriented overgrowth of pharmacolite $\left(\mathrm{CaHAsO}{ }_{4} 2 \mathrm{H}_{2} \mathrm{O}\right)$ on gypsum $\left(\mathrm{CaSO}_{4} 2 \mathrm{H}_{2} \mathrm{O}\right)$. Crystal Growth Design 7, 2756-2763.

Shannon, R.D., 1976. Revised effective ionic radii and systematic studies of interatomic distances in halides and chalcogenides. Acta Cryst. A32, 751-767.

Simón, M., Ortiz, I., García, I., Fernández, E., Fernández, J., Dorronsoro, C., Aguilar, J. 1999. Pollution of soils by the toxic spill of a pyrite mine (Aznalcóllar, Spain). Sci. Total Environ. 242, 105-115.

Traina, S.J., Laperche, V., 1999. Contaminant bioavailability in soils, sediments, and aquatic environments. Proc. Nat. Acad. Sci. USA 96, 3365-3371.

Tukker, A., Buist, H., van Oers, L., van der Voet, E., 2006. Risk to health and environment of the use of lead in product in the EU. Resour. Conservat. Recycl 49, 89-109

Valsami-Jones, E., Ragnardsotur, KV., Pumis, A., Bosbach, D., Kemp, A.J., Cressey, G. 1998. The dissolution of apatite in the presence of aqueous metal cations at $\mathrm{pH}$ 2-7. Chem. Geol. 151, 215-233. 